\title{
透析導入時上皮小体機能に関する検討
}

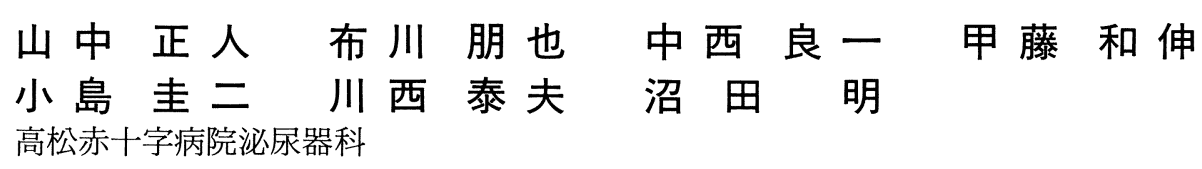

key words：透析導入，上皮小体機能

〈要旨〉

目的：透析導入期の上皮小体腫大の有無と血液生化学検査パラメーターとの関連を検討した.

対象と方法：透析導入患者 31 例 (男性 21 例, 女性 10 例) を対象とし, 頸部超音波検査および血液検査を施行し, これらの関連を検討した。

結果：上皮小体の腫大は 5 例（16\%）で認めすべて単発でサイズは長径 5〜10 mm であった。対象症例の年齢,

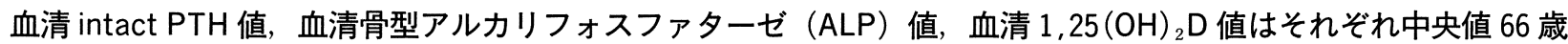
(40〜87)，210 pg/mL (6〜910)，20.9 U/L (14.1〜53.0)，7.4 pg/mL (3.6〜17.4) であった. 血清 intact PTH 值

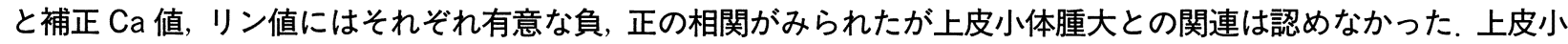
体腫大は補正 Ca 值が高値である場合と性別では女性において有意に高頻度で認められた。

結論：透析導入時に二次性上皮小体機能元進症 (2 HPT) による線維性骨炎を有している症例は少なかったが，す でに上皮小体の腫大を有する症例がみられており，保存期腎不全時期より 2 HPT に対し十分な管理, 治療が必要で あると考えられた。

\section{Clinical study of parathyroid function in end-stage renal failure}

Masahito Yamanaka, Tomoya Fukawa, Ryoichi Nakanishi, Kazunobu Katto, Keiji Kojima, Yasuo Kawanishi, Akira Numata

Department of Urology, Takamatsu Red Cross Hospital

Aims : To investigate hyperplasia of the parathyroid glands in end-stage renal failure, 31 predialysis patients were examined.

Results: Hyperplasia of a parathyroid gland $(\phi 5 \sim 10 \mathrm{~mm})$ was detected in only 5 patients by ultrasonography. There was no correlation between the serum parathyroid hormone level and hyperplasia of the parathyroid gland. However, there was a significant correlation between the serum corrected calcium level, sex and hyperplasia of the parathyroid gland.

Conclusion: We suggest that severe renal osteodystrophy is limited in end-stage renal failure. However, parathyroid gland hyperplasia developed in 5/31 (16.1\%) patients. We concluded that management of secondary hyperparathyroidism should be started early during the course of chronic renal failure.

\section{緒 言}

慢性腎不全症例にみられる腎性骨症は透析患者の QOL に関し多大な影響を及ぼす合併症である。腎不全 早期より骨の組織学的変化が認められ ${ }^{1)}$, 血中クレア
チニン值が $2 \mathrm{mg} / \mathrm{dL}$ を超えると血清 intact PTH 值 の上昇, 血清 $1,25(\mathrm{OH})_{2} \mathrm{D}$ 濃度の低下がみられると報 告されている2). 透析症例における $2 \mathrm{HPT}$ の治療に関

し, 至適血清 intact PTH 值や血清リン值の目標值は ほぼコンセンサスが得られている。ところが，保存期 腎不全期の目標値は議論の多いところである。今回,

山中 正人 高松赤十字病院泌尿器科 $\overline{7} 760-0017$ 香川県高松市番町 4-1-3

Masahito Yamanaka Tel :087-831-7101 Fax :087-837-8653

〔受付：平成 16 年 2 月 5 日，受理：平成 16 年 6 月 1 日〕 


\section{Serum Intact PTH(pg/mL)}

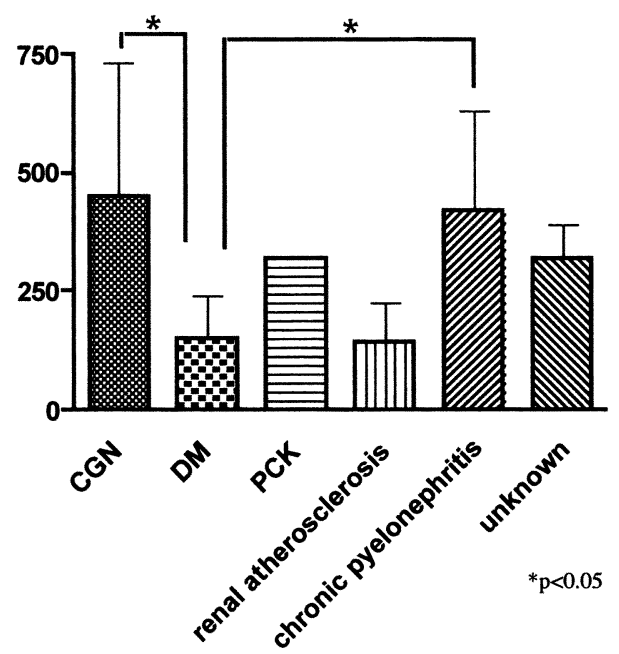

図 血清 intact PTH 值と原疾患の関係

われわれは透析導入期に内科的治療に抵抗をきたす3) と考えられる $2 \mathrm{HPT}$ の有無に関するレトロスペク ティブな検討を行った。

\section{I. 方 法}

2002 年に当院で透析を導入した 31 例を対象とし た。対象症例の年齢は中央值 66 歳 ( $40 \sim 87$ 歳), 性別 は男性 10 例, 女性 21 例であった。腎不全の原疾患は 慢性系球体腎炎 9 例, 糖尿病性腎症 13 例, 腎硬化症 3 例, 慢性腎孟腎炎 2 例, 霊胞腎 1 例, 不明 3 例であっ た。透析導入期に頸部超音波検查（東芝メディカル社 製 APLIO，プローブ $11 \mathrm{MHz}$ ) と血液生化学検査を施 行し,これらの関連を検討した. 頸部超音波検查は 1 人 の放射線科医師により施行された，血液検査は透析導 入日の透析前に採取した。各種検査所見の統計処理は SAS 社製統計解析ソフト Stat View (5.0)を用いて行 い $\mathrm{p}<0.05$ で有意差ありとした.

\section{II. 結 果}

\section{1. 透析導入時ビタミン D，カルシウム凮内服状況}

カルシトリオール剤 $(0.25 \mu \mathrm{g} /$ 日 ) と沈降炭酸カル シウム剂 $(1.5 \mathrm{~g} /$ 日) 併用が 2 例, 沈降炭酸カルシウム 骭 $(1.5 \mathrm{~g} /$ 日) 単独が 6 例, 沈降炭酸カルシウム剤 ( 3.0 $\mathrm{g} /$ 日) 単独が 2 例に投与されていた。 その他の 21 例に はカルシトリオール㓲と沈降炭酸カルシウムは投与さ れていなかった。
表 1 血清 intact PTH 值との関連

\begin{tabular}{lrc}
\hline & 相関係数 & \multicolumn{1}{c}{$\mathrm{p}$ 值 } \\
\hline 年齢 & -0.403 & 0.0245 \\
血清クレアチニン值 & 0.603 & 0.0003 \\
血清補正カルシウム值 & -0.504 & 0.0038 \\
血清リン值 & 0.614 & 0.0003 \\
血清骨型 ALP 值 & 0.318 & 0.0863 \\
血清 $\mathrm{pH}$ 值 & -0.487 & 0.0054 \\
血清 $1,25(\mathrm{OH})_{2} \mathrm{D}$ & -0.093 & 0.6192 \\
\hline
\end{tabular}

\section{2. 透析導入期血液生化学所見の結果}

血清クレアチニン值は中央值 $7.8 \mathrm{mg} / \mathrm{dL}(3.5 \sim$ $21.3 \mathrm{mg} / \mathrm{dL})$, 血中補正カルシウム值は中央値 8.8 $\mathrm{mg} / \mathrm{dL}(5.4 \sim 9.9 \mathrm{mg} / \mathrm{dL})$ ，血清リン值は中央值 5.5 $\mathrm{mg} / \mathrm{dL}(3.2 \sim 9.0 \mathrm{mg} / \mathrm{dL})$ であった. 血清 intact PTH 值 (Chemiluminescent immunoassay 法) が $200 \mathrm{pg} /$ $\mathrm{mL}$ 以上であった症例は 17 例 $(54.8 \%), 100 \mathrm{pg} / \mathrm{mL}$ 以下であった症例は 3 例 $(9.7 \%)$ であった，血清骨型 ALP 值 (Enzyme immunoassay 法) が高值であった 症例は 1 例 $(3.2 \%)$ のみであった。血清 $1,25(\mathrm{OH})_{2} \mathrm{D}$ 值 (Radio immunoassay 2 抗体法) は全例低値であっ た。

\section{3. 血清 intact PTH 值と慢性腎不全原疾患の検討}

図のように原疾患により透析導入期の血清 intact PTH 值に有意な差を認めた (Kruskal-Wallis の検 定： $\mathrm{p}=0.0256)$. 慢性系球体腎炎と糖尿病性腎症, 慢 性腎孟腎炎と糖尿病性腎症の間で有意差がみられた (Mann-Whitneyの U 検定：それぞれ $\mathrm{p}=0.0101$ ， $\mathrm{p}=0.0415)$.

\section{4. 血清 intact PTH 值と年齢, 血液生化学検査の関連}

表 1 のように血清 intact PTH 值と年齢, 血清クレ アチニン值, 血中補正カルシウム值〔血清アルブミン 值が $4.0 \mathrm{~g} / \mathrm{dL}$ 末満時に（血中 $\mathrm{Ca}$ 值 +4 -血中アルブ ミン值）で補正了，リン值， $\mathrm{pH}$ 值との間に有意な相関 関係を認めた。ステップワイズ回帰分析の結果，血清 intact PTH 值は血中補正カルシウム值（標準回帰係 数：-0.424）とリン值 (標準回帰係数：0.429)の 2 独 立変数により $52.3 \%$ 説明できる検査であった（R 2 乗 值 0.523 , 回帰分析 $\mathrm{p}<0.0001$ ).

\section{5. 上皮小体腫大の有無に関する検討（表 2)}

頸部超音波検査で上皮小体の腫大を認めた症例は 5 例（16.1\%）であった．全例単発の腫大で大きさは長 径 5 10 mm であった．血液生化学検査では血中補正 カルシウム值のみが腫大の有無により有意差がみら れ, 腫大群は血中補正カルシウム值が高值であった(腫 大群 $9.5 \pm 0.3 \mathrm{mg} / \mathrm{dL}$ (平均值士標準偏差), 非腫大群 $8.4 \pm 1.1 \mathrm{mg} / \mathrm{dL}$ (平均值士標準偏差), Mann-Whit- 
表 2 上皮小体腫大の有無

\begin{tabular}{lccc}
\hline & hyperplasia $(-)$ & hyperplasia $(+)$ & $\mathrm{p}$ 值 \\
\hline Age & $66 \pm 13$ & $69 \pm 11$ & $\mathrm{p}=0.5546$ \\
Female/Male & $6 / 20$ & $4 / 1$ & $\mathrm{p}=0.0274$ \\
Therapy +/ & $8 / 18$ & $2 / 3$ & $\mathrm{p}=1.0000$ \\
血清 intact PTH 值 & $278 \pm 221$ & $272 \pm 200$ & $\mathrm{p}=0.7883$ \\
血清クレアチニン值 & $8.7 \pm 4.6$ & $8.3 \pm 4.8$ & $\mathrm{p}=0.8932$ \\
血中補正カルシウム值 & $8.4 \pm 1.1$ & $9.5 \pm 0.3$ & $\mathrm{p}=0.0108$ \\
血清リン値 & $5.8 \pm 1.7$ & $5.5 \pm 0.8$ & $\mathrm{p}=0.9570$ \\
血清骨型 $\mathrm{ALP}$ 值 & $23.1 \pm 8.7$ & $23.8 \pm 7.0$ & $\mathrm{p}=0.6807$ \\
血清 $1,25(\mathrm{OH})_{2} \mathrm{D}_{3}$ 值 & $7.7 \pm 2.6$ & $8.1 \pm 6.4$ & $\mathrm{p}=0.4821$ \\
血清 $\mathrm{pH}$ 值 & $7.34 \pm 0.09$ & $7.36 \pm 0.04$ & $\mathrm{p}=0.6099$ \\
\hline
\end{tabular}

Therapy：カルシトリオール and/or 沈降炭酸カルシウム剤の内服

ney の U 検定： $\mathrm{p}=0.0108)$ ．また，腫大群では有意に 女性が多かった（Fisher の直接法： $\mathrm{p}=0.00274 ）$.

\section{III. 考 察}

慢性腎不全による 2 HPT は透析患者の QOL に多 大な影響を及ぼす合併症である。透析骨症や尿毒素と しての $\mathrm{PTH}^{4)} に よ る$ 血管障害を含めた臓器障害に対 し透析医は予防拉よび適切な治療を心がける必要があ る。しかし，近年高齢者透析導入症例の増加および原 疾患が糖尿病性腎症である透析症例の増加により典型 的な線維性骨炎を伴った 2 HPT 例は減少しており, 無形成骨を合併した上皮小体機能低下症が増加してい る。このような背景下で，透析導入期に内科的な治療 で抵抗する ${ }^{3)}$ 考えられる上皮小体の腫大を伴った 2 HPT の頻度を検討する目的でレトロスペクティブな 臨床的検討を行った。

2002 年に当科で 31 例の末期腎不全症例に透析を導 入し, 年齢の中央值が 66 歳で高齢者が多かった。導入 時の血清 intact PTH 值は中央值 $210 \mathrm{pg} / \mathrm{mL}$ で 200 $\mathrm{pg} / \mathrm{mL}$ 以上であった症例は 17 例 $(54.8 \%)$ であった. また， $100 \mathrm{pg} / \mathrm{mL}$ 以下であった症例は 3 例 (9.7\%) で あり, 透析導入時血清 intact PTH 值は比較的高值で あった5). しかし，血清骨型 ALP 值が $53 \mathrm{U} / \mathrm{L}$ と高値 であった症例は 1 例のみであり線維性骨炎を伴ってい ると考えられる症例は少なかった。慢性腎不全による $2 \mathrm{HPT}$ の発生機序はリンの蓄積に対する代償による とする Bricker ら ${ }^{6)} の$ Trade-off theory, Massry ら ${ }^{7)}$ の骨の PTH に対する抵抗によるとする説, Slatopols$\mathrm{ky} ら^{8)}$ のリンの上皮小体に対する直接作用によるとす る説がある。本検討でも透析導入期症例の血清 intact PTH 值は血清リン值, 血中補正カルシウム值と有意 な関連を認めた。しかし，血清 intact PTH 值は頸部 超音波検査による上皮小体の腫大の有無とは有意な関
連がみられなかった。これは，本論文の対象症例の導 入時年齢が中央值で 66 歳と高齢であったことや糖尿 病性腎症例が 13 例と多かったことによるものに起因 するかもしれないが，近年の透析導入時における特徵 でもあり，導入時の上皮小体機能を考察する上で問題 となるものではないと思われる。また，頸部超音波検 査の腫大上皮小体検出感度は 34～92\% (平均 65\%)， 偽陽性率は 4～25\%（平均 12.5\%）と報告されてお $\eta^{9)}$ ，検査時に腫大腺の見逃し等の影響が加わった可 能性があると考えられた。

透析導入時，超音波検査により $5 / 31$ 例 (16.1\%) で 上皮小体の腫大がみられたが全例単発で，大きさは長 径 5〜10 mm 大であった。腺重量は超音波検査により 3 方向 $(\mathrm{A}, \mathrm{B}, \mathrm{C})$ を測定し， $\mathrm{A} \times \mathrm{B} \times \mathrm{C} \times \pi / 6$ の数式 をあてはめることによって推測できると報告されてお $\eta^{10)}$ ，今回検出できた上皮小体の重量は全例 $500 \mathrm{mg}$ 以下であると考えられ，これらの腫大腺は結節性過形 成である頻度は少なく ${ }^{11)}$ カルシトリオール剤を含めた 内科的治療に反応すると思われる ${ }^{3)}$.

超音波検査による上皮小体の腫大は血中補正カルシ ウム值が高值である場合と性別が女性である場合に有 意差をもって高頻度に認められた。透析導入前にビ夕 ミン D か沈降炭酸カルシウム剤を服用していた症例 は $10 / 31$ 例 $(32.3 \%)$ で服用の有無で血中補正カルシ ウム值と腫大腺の有無に統計学的な有意差はみられな かったが（血中補正カルシウム值：服用群 $8.6 \pm 0.9$, 非服用群 8.5 \pm 1.2. Mann-Whitney の U 検定 $: \mathrm{p}=$ 0.9663. 腫大腺の有無: Fisher's Exact Test $: p=$ 1.0000), 血清 intact PTH 值は服用群で高值であった (服用群 $403.0 \pm 264.5$, 非服用群 $216.6 \pm 160.5$. Mann-Whitney の U 検定 $: p=0.00424)$ 。したがって 血中補正カルシウム值の上昇は内服薬による影響は少 ないと思われ，透析導入期における上皮小体の腫大を 示唆できる因子と考えられた。今後さらに症例を蓄積 
し，透析導入前後の治療や性別等の因子と上皮小体腫 大の変化を検討することが重要である.

PTH は尿毒症性物質であり, 透析導入前の生体に 影響を与えていると考元られる ${ }^{4)}$. しかし, 本研究の対 象症例では比較的血清 intact PTH 值が高值であった にもかかわらず高度な腎性骨症を有する症例は認めら れなかった。しかし，透析導入期にすでに上皮小体の 腫大を有する症例がみられており保存期腎不全時期よ り 2 HPT に対し十分な管理, 治療が必要であると考 えられた。

本論文の要旨は, 第 48 回日本透析医学会 (2003.6. 大 阪）で発表した。

\section{文献}

1) Ritz E, Malluche HH, Krempien B : Bone histology in renal insufficiency. Davis, ed: Perspectives in nephrology and hypertention. New York, Willey, p 197-233, 1977

2) Martinez I, Zaracho R, Montenegro J : The role of calcitriol in the secondary hyperparathyroidism of chronic renal failure. J Am Soc Nephrol 4:725, 1993

3) Fukagawa M, Kitaoka M, Yi H, Fukuda N, Matsumoto T, Ogata E, Kurokawa $\mathrm{K}$ : Serial evaluation of parathyroid size by ultrasonography is another useful marker for the long-term prognosis of calcitriol pulse therapy in chronic dialysis patients. Nephron $68: 221-228,1994$
4）丹羽利充：尿毒症物質としてのPTH. 腎と骨代謝 $16: 175-178,2003$

5）塚本雄介：透析前腎不全. 腎と骨代謝ハンドブック(黒 川清, 鈴木正司, 秋澤忠男, 松本俊夫, 塚本雄介編), p 187-195, 日本メディカルセンター, 東京, 1997

6) Slatopolsky E, Bricker NS : The role of phosphorus restriction in the prevention of secondary hyperparathyroidism in chronic renak failure. Kidney Int 4 : 141-145, 1973

7) Massry SG, Coburn JW, Lee DB, Jowsey J, Kleeman $\mathrm{CR}$ : Skeletal resistance to parathyroid hormone in renal failure : Study in 105 human subjects. Ann Int Med 78: 357-364, 1973

8) Slatopolsky E, Finch J, Denda M, Ritter C, Zhong M, Dusso A, MacDonald PN, Brown AJ : Phosphorus restriction prevents parathyroid gland growth. High phosphorus directly stimulates PTH secretion in vitro. J Clin Invest $97: 2534-2540,1996$

9) Doppman JL, Miller DL : Localization of parathyroid tumors in patients with asymptomatic hyperparathyroidism and no previous surgery. J Bone Miner Res 6 : S153-S159, 1991

10) Giangrande A, Castiglioni A, Solbiati L, Allaria P : Ultrasound-guided percutaneous fine-needle ethanol injection into parathyroid glands in secondary hyperparathyroidism. Nephrol Dial Transplant 7 : 412-421, 1992

11）冨永芳博, 田中勇治, 高木 弘：特集腎性上皮小体機 能充進症. 病理組織と病態生理. 内分泌外科 $14: 87-$ 95, 1997-6 